\title{
VERNACULAR HOUSING IN ALGIERS: A SEMANTIC AND PASSIVE ARCHITECTURE
}

\author{
L. ADLI-CHEBAIKI \& N. CHABBI-CHEMROUK \\ Laboratoire Architecture et Environnement, Ecole Polytechnique d'Architecture et d'Urbanisme, Algeria.
}

\section{ABSTRACT}

This paper examines passive systems in vernacular housing in Algiers, using the villa Abd-el- as a case study. It may contribute towards potential solutions for the world energy crisis and provides an example of the maintenance and development of semantic criteria. A synthesis of both semantic and passive principles, the villa Abd-el-Tif, is one of the best examples of the harmonization of interior comfort, stylistic attributes and pleasant views.

This paper describes the role of the stylistic and architectural elements that contribute to the comfort of vernacular houses in Algiers, in terms of passive systems. The villa Abd-el-Tif consists of elements including the west ed-dar (central courtyard), s'hin (galleries), $k^{\prime}$ bou (ancillary rooms topped with a cupola) and minzah (terraces) that make up a passive cooling and ventilation system in summer.

Finally, the role of architectural design in the creation of passive systems that are in harmony with regional climatic conditions is described using a qualitative approach and a representative example.

Keywords: passive system, semantic criteria, stylistic elements, vernacular architecture.

\section{INTRODUCTION}

In the Muslim world, and more specifically in the North African context, architectural forms have developed as a result of knowledge transfer from middle east and Muslim civilizations during the middle ages [1]. This architecture, which was grafted onto existing traditional Berber foundations, was then came into contact with Muslim Spain and led to a subtle fusion between its clear semantic conventions and vernacular construction principles [2].

Several famous architects took an interest in this type of architecture, which led Le Corbusier to say, about their constructor, 'He is more of an architect than ever before. He is like those who built the houses of past times, when everything was present: the best techniques, the most effective, pleasant, fertile and economic dimensions and attitudes, where wisdom reigned and was expressed by poetry... until the day when schools were established, and with them, academicism' [3].

Today, vernacular architecture is closely linked to passive construction systems, which in turn is linked to contemporary environmental challenges that contribute to maintaining balanced and sustainable development [4]. It is the subject of renewed interest in its construction principles and the popularization of its so-called 'architectural' lessons [5].

This passive system is based on several architectural elements that will be developed in this paper. These elements send back, on the one hand, to the architectural typology and the shape, and on the other hand, to stylistic attributes, which give some semantic criteria. Among these latter, we will study, through the villa Abd-el-Tif, the role of the central courtyard (called west ed-dar), the galleries (called S'hin), the k'bou (small ancillary room) and the minzah (terrace), by using a qualitative approach.

\section{METHODOLOGY}

This article uses a qualitative approach based mainly on an analysis for vernacular climatic responsive strategies, used in Algiers' vernacular architecture. This approach ensues from a reflexive way of perception [6]. The reflexive way studies the phenomenal appearances of the shape, relatively to

(C) 2015 WIT Press, www.witpress.com

ISSN: 1755-7437 (paper format), ISSN: 1755-7445 (online), http://www.witpress.com/journals

DOI: $10.2495 / \mathrm{DNE}-\mathrm{V} 10-\mathrm{N} 2-154-164$ 
certain point of view, which is in our case, the passive system and comfort solutions. In addition, stylistic attributes are important in this case study and help in the elaboration of an aesthetic description of the space. The qualitative approach is used by the inquirer to make knowledge claims based primarily on constructivist perspectives [7].

This qualitative approach is applied to a country house of the ottoman period situated in Algiers. The analysis contributes to strengthening knowledge about traditional devices and know how on passive systems leading in the long term to the elaboration of innovative solutions based on a real understanding of existing relations with critical thinking [7].

\section{THE ALGIERS COUNTRY VILLA: A SUMMER HOUSE}

The vernacular architecture of traditional Algiers' villas can be divided into two types: the (intramural) urban house and the (extramural) country house (see Fig. 1). Respecting the typology of medieval Muslim cities [8], the specific characteristic of urban houses in Algiers lies in the complex relationships that exist between them, and the deep and close links between volumes and construction [9]. This is due to the fact that they follow the same organizational and construction principles and respond to similar morphological and climatic conditions. Typically, the site lies on a coastal slope, similar to an amphitheatre [5], exposed to the gentle Mediterranean climate. The main characteristic of most of these houses is a patio (central courtyard).

Given that the patio tends to be positioned as centrally as possible on the plot [5], its dimensions and the number of galleries depend on the dimensions of the plot, its position with respect to the arrangement of neighbouring houses and the relationship with contiguous properties [10, 11]. Its galleries provide protection against the climate and guide the layout of rooms and other internal spaces (Fig. 1).
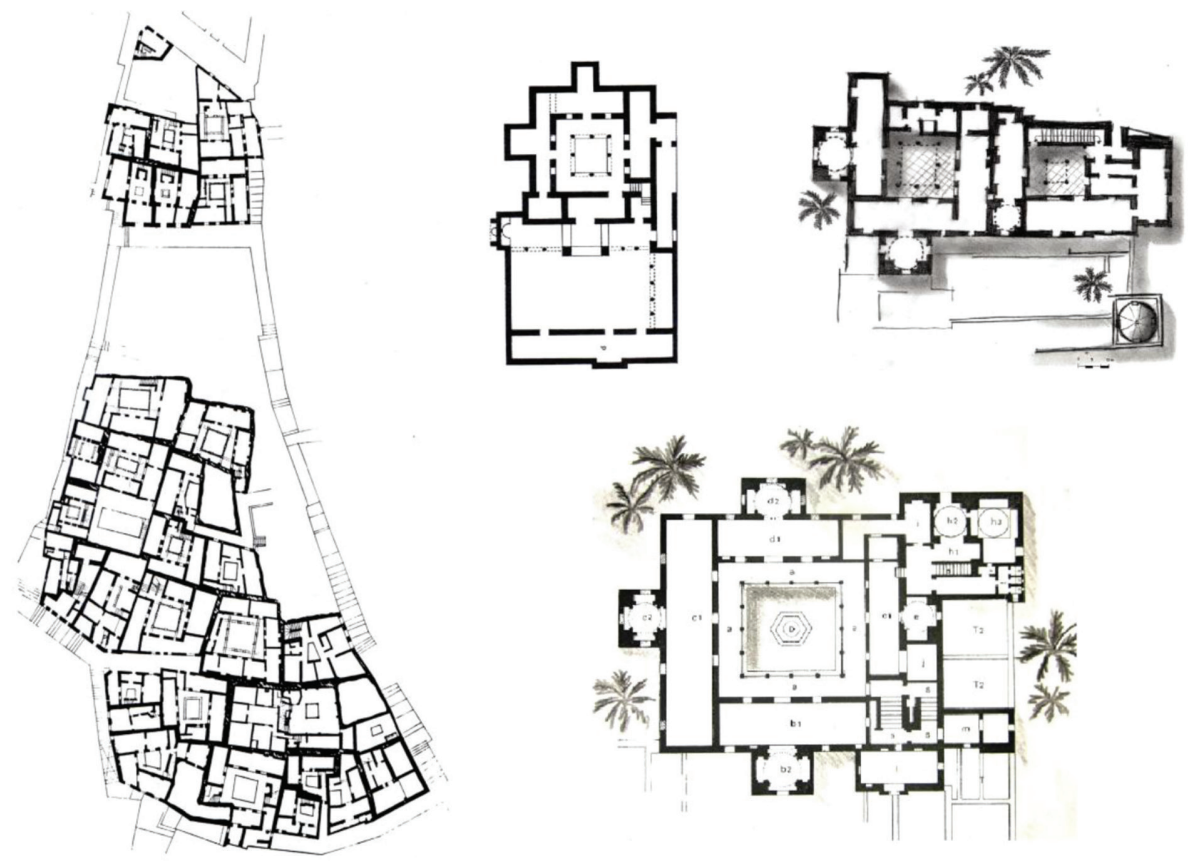

Figure 1: A comparison between intra-mural typology (left) and extra-mural typology (right). 
Country houses were built around the medina (historical city). Most of these villas housed consuls, deys and pashas during the Ottoman period. Some were occupied by soldiers following 1830 (the beginning of French colonization), while others were abandoned [12,3].

The few documented examples of this typology confirm its architectural interest [13], which manifests in internal spaces that remain pleasant even during the hottest days of the year. In addition, there is a scrupulous respect for form, and the use and identity of the place in the architectural syntax [9].

Several historical studies have compared the specific features of the typology [12,14-16]. These studies confirm the layout of Algiers' country houses, which were built on slopes or at the foot of valleys bordering the historic city. These houses had the biggest courtyards, and the neighbouring spaces were transformed into gardens. Consequently, the relative availability of space made it possible to extend the property, through a multiplication of planted or arboreal courtyards that were either walled or bordered by covered galleries that served as corridors or resting areas. The architecture of such houses juxtaposed these elements to achieve a subtle harmony between nature, internal comfort and clear semantic characteristics (Fig. 1).

\section{THE VILLA ABD-EL-TIF}

Built in the middle of the 17th century, the villa Abd-el-Tif is situated in the Bois des Arcades in the El Hamma quarter of Algiers; the area was formerly a wood, known for its numerous sources of water. The villa was restored for the first time in 1907 and became a residence for European artists; it was restored again in 2005 and became an exhibition space and a place for artists to meet. Even before an extension was added in 1905 that included art workshops and studios, the site already consisted of a complex of several elements: the main house (the villa Abd-el-Tif), the ryadh (a covered space to relax in), covered galleries and a guest house (the douéra) [17].

The villa was situated on sloping ground, around $100 \mathrm{~m}$ above the sea level. It also benefitted from the Mediterranean climate and for a wooded area that had formerly been a garden, known as the fahs during the Ottoman period. The wood was damp and crossed by underground watercourses. Consequently, the house is notable for its multiple wells, water bodies and conduits known as noria, which fed various ponds and provided the house and the garden with water [16] (see Figs 2 and 3).

The main house, which we discuss in this paper, consists of a central courtyard dominated by a large terrace that looks out over the bay of Algiers. Its construction principles are consistent with vernacular architecture in the Algiers context; consequently, the use of the villa's spaces reflects an interesting harmonization with nature and provides subtle solutions that optimize internal comfort $[12,14]$. The villa's vernacular construction principles and its semantics (seen in its architectural language) led to the emergence of a series of elements that were both stylistic and passive. For example, the west ed-dar (central courtyard) indicates the villa's centre or heart; s'hin (galleries) are composed of arches; the $k^{\prime} b o u$ is an alcove topped with a cupola; the menzah is an accessible terrace; while the driba (main entrance) provides indirect access to internal spaces and functions as a reception area for guests. Finally, the noria and the djeb were used for irrigation and water storage (see Figs 2 and 3).

\subsection{The west ed-dar (the central courtyard)}

The main characteristic of Arab-Muslim villas is the organization of spaces around a central courtyard (Figs 1 and 4). Considered to be the heart of the house, this space heats and cools adjacent rooms, and provides psychological support [5]. The west ed-dar is closely connected with the culture and climate of Algiers, and its surrounding areas. It provided not only tranquillity and safety 


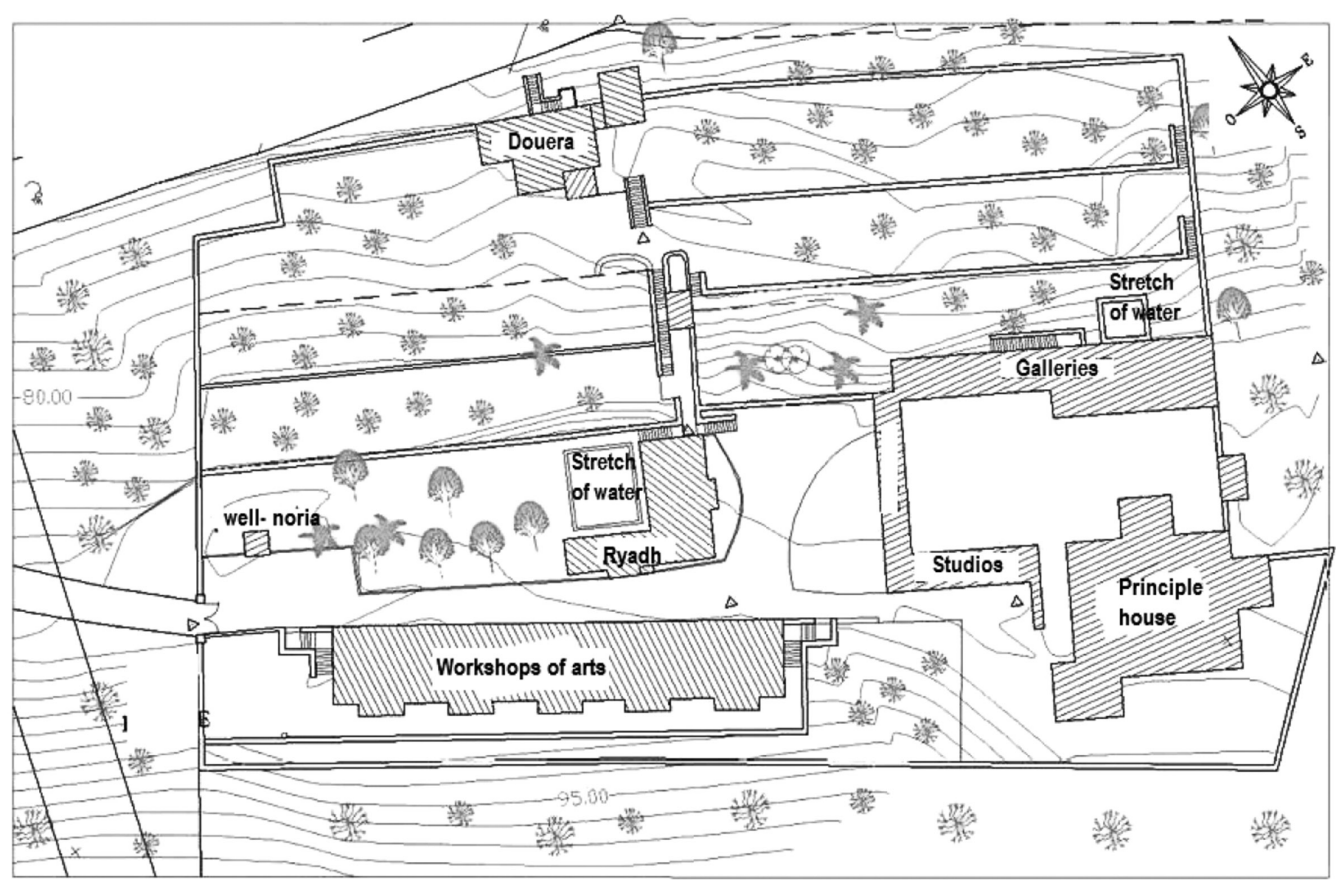

Figure 2: A general plan of Abd-el-tif house and its bodies (http://openbuildings.com).

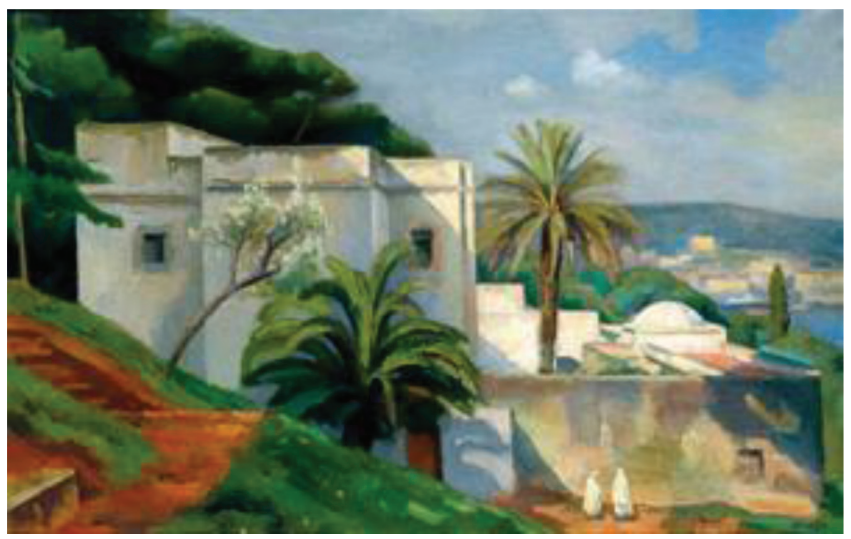

Figure 3: A painting of Albert Brabo of the villa Abd-el-Tif (http://www.arcadja.com).

but also a cool environment, which was particularly welcome in summer [4]. Cooling is provided by two natural ventilation mechanisms, depending on the size and layout of the internal spaces and openings [18].

The proportions of the courtyard and its shaded areas generate a microclimate that is reinforced by plants and water features (a fountain). Transverse ventilation is the result of wide openings into the courtyard, which allow the extraction of hot air through small openings and alcoves situated in 


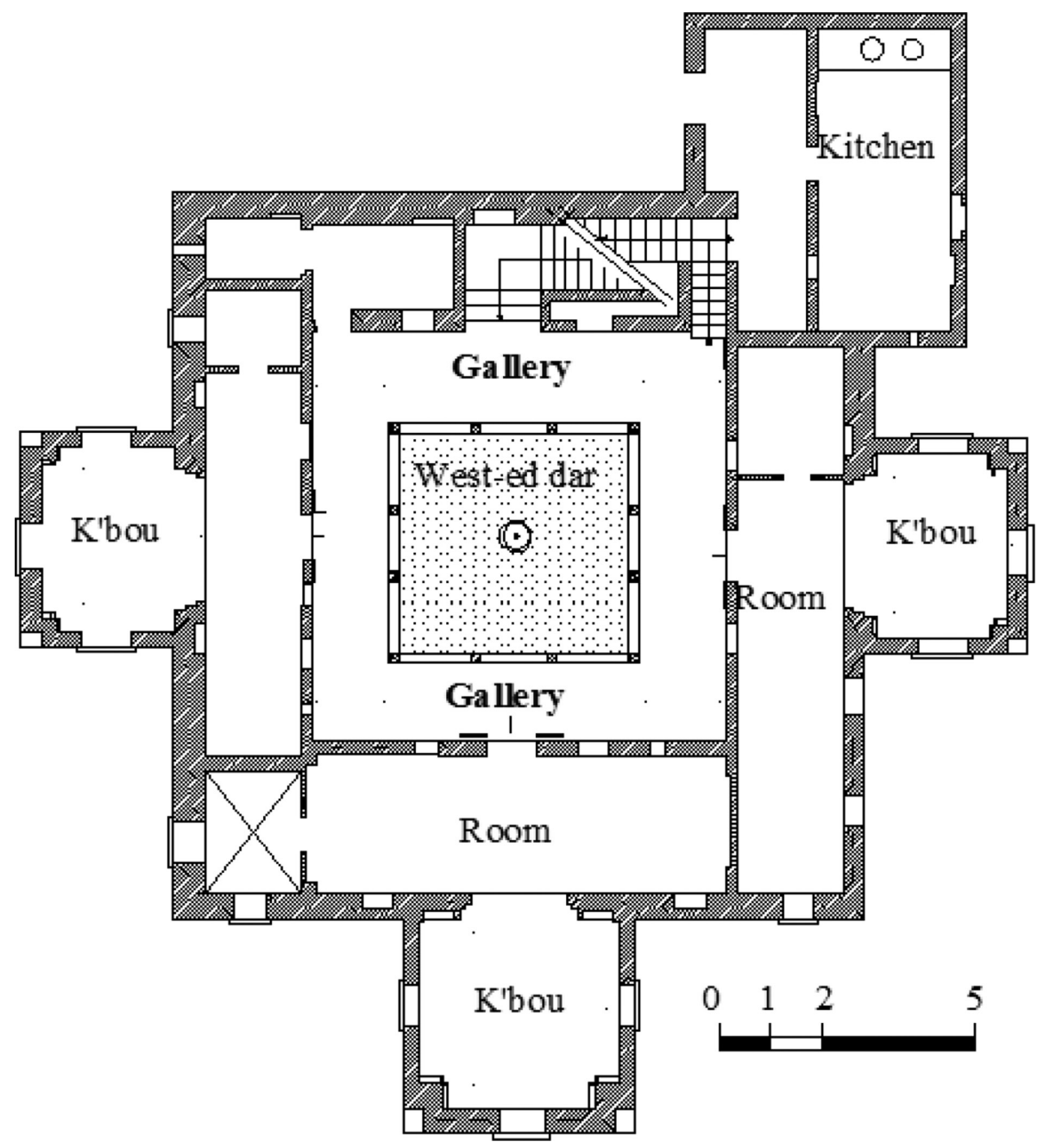

Figure 4: First floor of the villa Abd-el-Tif.

the villa's external walls. This natural ventilation is amplified by the villa's orientation, which takes advantage of the prevailing north-east wind (from the Mediterranean sea). The chimney ventilation effect is the result of opening up the central courtyard to the sky. In addition, the many small spaces that open off each main room are topped by eight-sided gored cupolas, which facilitate the evacuation of hot air [19].

The overall design is focused on the square central courtyard, which all the other rooms open onto. Galleries line all sides of the courtyard and have the following functions and role in cooling interior spaces:

- Daytime: The sun heats the gallery walls that face the courtyard. Hot air rises providing natural ventilation. In addition, massive walls (brick earth) and floors protect interior spaces from direct solar radiation. 
- Night-time: Cool air descends into the courtyard and enters the rooms that open onto it. The flat roof and thick walls also improve the cooling system.

- Evening: Long shadows quickly protect the courtyard from the sun's heat.

4.2 Vegetation and water in the west ed-dar

Vegetation, in the form of plants and flower beds, humidifies and refreshes the air in all the spaces that surround the west ed-dar [4]. The courtyard, which is under $25 \mathrm{~m}^{2}$ and one storey high (Figs 4 and 5), has an oriental fountain at the centre. While the fountain itself does not take up more than $2 \mathrm{~m}^{2}$, the surface of the water body around the ryadh is around $25 \mathrm{~m}^{2}$ (Fig. 6). The latter is one of the biggest water basins of the period [17].

\subsubsection{Materials used in the west ed-dar}

The main building material is baked earth bricks. These bricks have a high thermal capacity; they adjust to diurnal thermal changes and have low thermal transmission [4]. They are also an effective insulating material. They are white, which reflects $70 \%$ of solar radiation, and their toughness limits the absorption of the sun's rays. Walls are thick and covered with ceramic tiles, which affects the size of the villa's interior spaces.

\subsubsection{Joinery in the west ed-dar}

The main door opens into a small room, which plays the dual role of separating private and public spaces and acts as a reception area. However, all of the other doors to the main rooms are in the gallery. These large, wooden, double doors are completely independent of the surrounding masonry. They can be folded wide open, to optimize natural ventilation and cool the room. Three decorative

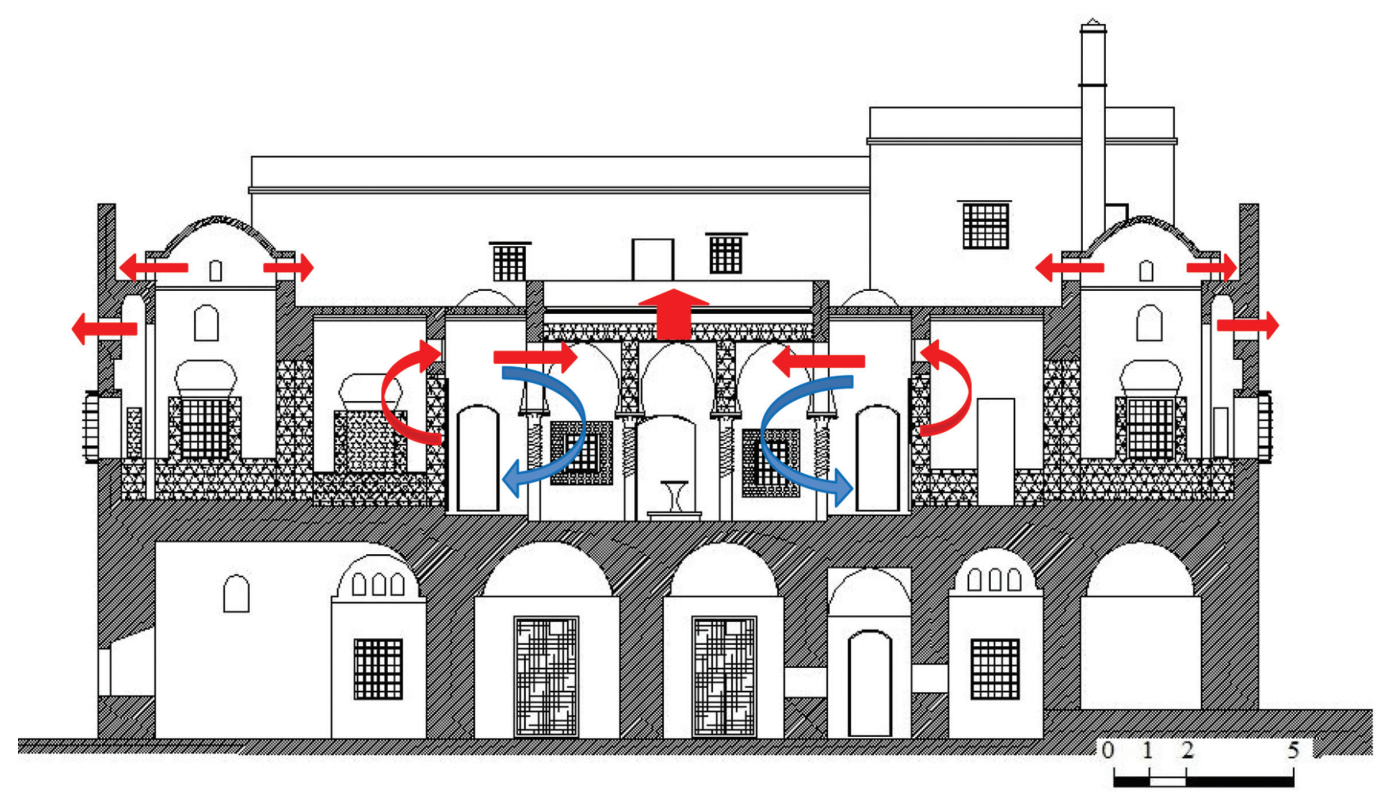

Figure 5: Existing wind in the central courtyard. 


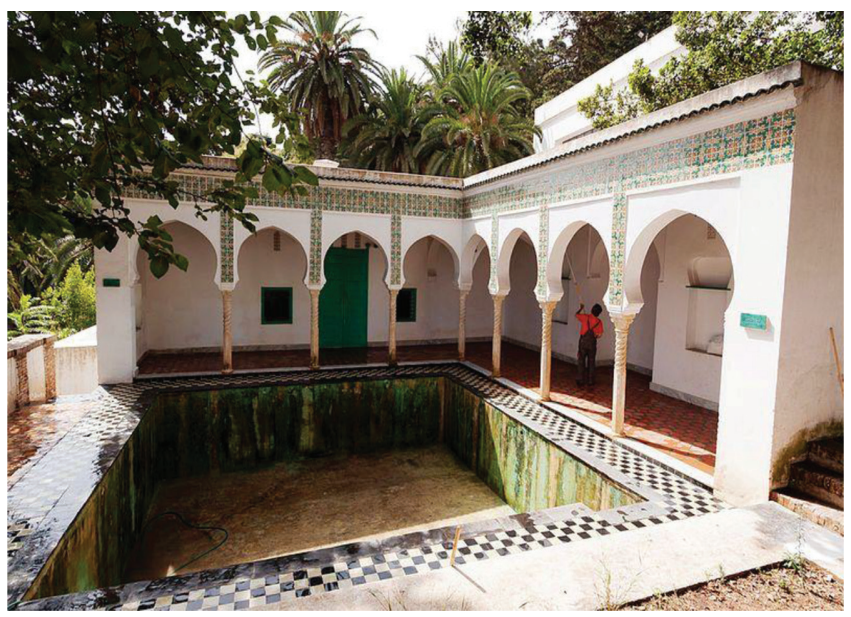

Figure 6: A view of the Ryadh (http://openbuildings.com).

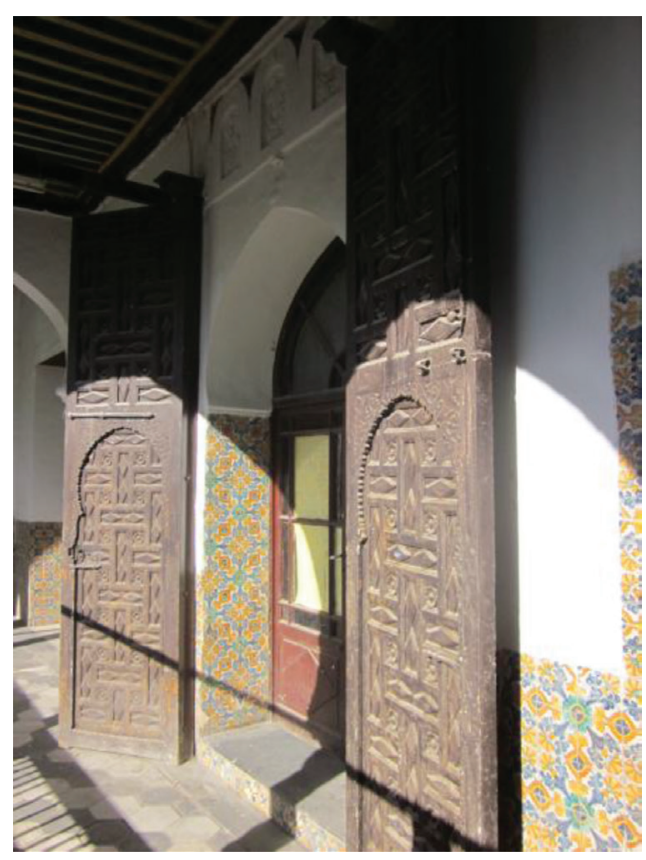

Figure 7: A view of a door of a main room.

openings above the doors optimize the chimney effect when they are closed. 'In Algiers the door is basically created by the climate. It could not exist at other latitudes. This is clearly shown by the fact that at the same latitudes, it is the best expression of its function in its climate' [5].

Each leaf of these doors contains a smaller door that is around the size of a person, and their size is coherent with the culture and the decoration of the place. The dimensions of these doors (about $3.5 \mathrm{~m}$ ), and the fact that they can be fully opened or partially closed (to speed up or slow down air circulation) without compromising their usual function shows that they respond to the requirements of the location's weather and climate (Fig. 7). 


\subsection{The s'hin (gallery)}

A s'hin (gallery) is an intermediate space situated between the main room and the central courtyard. The villa Abd-el-Tif's s'hin consists of four covered galleries that surround the courtyard (Fig. 4). They are supported by spiral columns and Gothic (broken) arches. They are distributed throughout the villa, and both provide shade and prevent the sun hitting internal walls. These walls are around 0.6-m thick, and both the internal and external surfaces are covered with ceramic tiles up to a height of $0.9 \mathrm{~m}$, which improves heat insulation.

These shady galleries and the courtyard are cooler during summer nights. Lighter, less dense hot air from indoors travels upward and creates a pressure gradient that allows air to escape from high openings and the galleries. Moreover, the villa uses an open-plan design for natural ventilation. The principal rooms are connected to the $k^{\prime}$ bou (ancillary rooms), which ensures that convection pushes hot air out of the openings in the cupolas. This demonstrates the natural ventilation and cooling system that was designed for the villa to cope with hot weather.

\subsection{The k'bou (small ancillary room)}

A $k^{\prime} b o u$ generally consists of a square volume that opens off a main room, with windows in each of its facades that look out onto the gardens. In the villa Abd-El-tif, the $k^{\prime} b o u$ are large compared with other country houses. They are similar in size to the main rooms, particularly on the north-east side, to catch the prevailing wind (Fig. 8). Their direct connection to the main rooms and open plan (surrounding the central courtyard) amplifies transversal air currents. Hot air extraction is increased by an eight-sided cupola with ventilation openings on four sides, together with other openings that surmount each window and door (see Fig. 5).

On hot days, the effects of direct sunshine are reduced through the central courtyard's wide $(1.80 \mathrm{~m})$ galleries, and ceramic tiles that cover the arcades on the one hand, and the lower parts of the walls of internal rooms, on the other hand. At the same time, the $k^{\prime} b o u$ that are connected to the
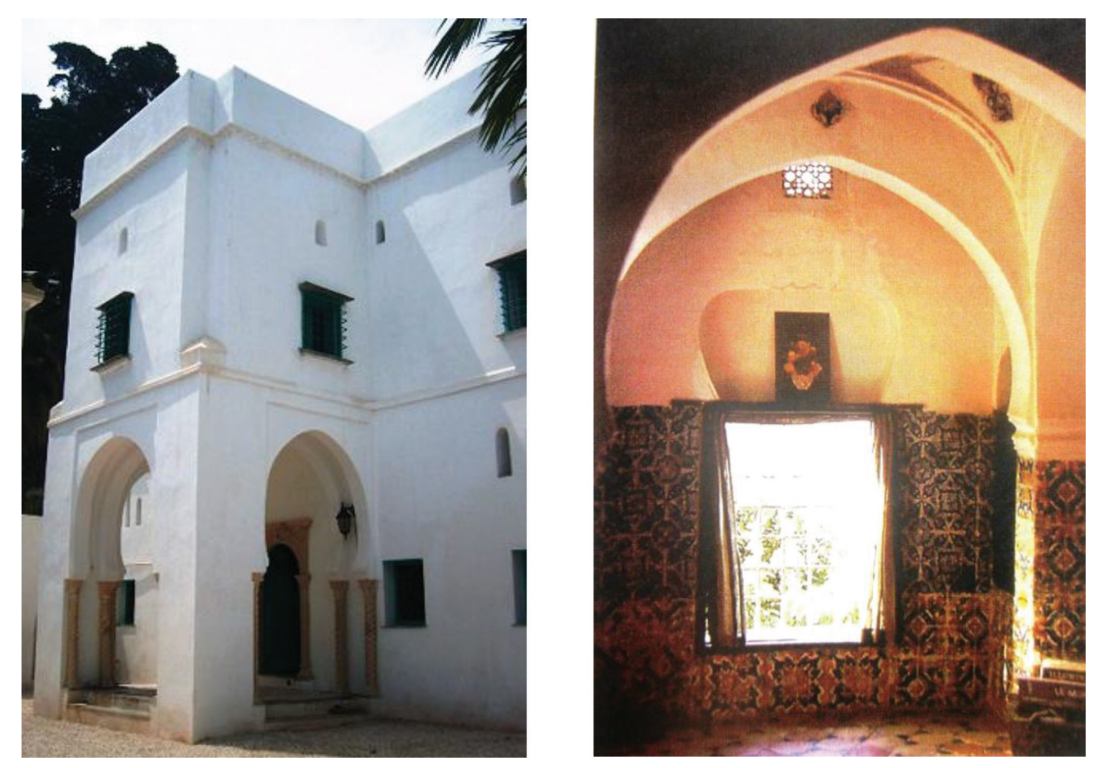

Figure 8: (a) Exterior view of k'bou. (b) Interior view of $k^{\prime} b o u$ [5]. 
main rooms extract hot air through their high openings and the chimney effect. Low windows, often found in three of the facades of the k'bou, allow the flow of fresh air and optimize transverse ventilation (Fig. 5). It should also be noted that all of the internal surfaces of both the main rooms and the k'bou are covered with ceramic tiles, which create a fresh environment and improve insulation.

\subsubsection{Summer, daytime}

During daytime in summer, the upper layer of the air in the main rooms is hotter than air lower down, due to the proximity of hot materials and exposure to solar radiation [4]. In general, hot air escapes through the high openings or the cupola of the k'bou (where there is no wind). In addition, air entering from the courtyard loses heat and becomes moist, due to the shade and the fountain. This fresh air circulates into the different spaces.

\subsubsection{Summer, night-time}

At night, the upper layer of air is cooler than lower layers, because of thermal reflection from materials and external cool air. Therefore, dense cold air falls, while lighter hot air rises and escapes through openings. Air from the courtyard becomes moist when passing over the fountain and circulates to other spaces.

\subsection{The minzah (terrace)}

The minzah is an essential element in the architecture of country houses around Algiers. It offers a pleasant view over the sea and neighbouring gardens and provides, through openings in the cupolas of the k'bou, natural ventilation and fresh air thereby acting as a fifth facade.

Low walls function as railings; depending on the orientation of the internal walls they house two types of evacuation conduit. The first allows the evacuation of smoke from oil lamps used at night; the second allows the evacuation of rain-water that collects on the terrace. These conduits are also integrated into the internal walls of the building and draw water to an underground reservoir, called the jeb [11]. In this case, water that crosses the internal walls of rooms cools them. Moreover, smoke conduits allow the circulation of fresh air through rooms during the day.

\section{DEPENDENCES OF THE VILLA ABD-EL-TIF}

Dependences of the villa Abd-el-Tif consist of many bodies (Fig. 2). Among these latter, we are interested by the noria and the gardens, which contribute in their turn, to the complex system of the villa.

\subsection{The noria (water conduit)}

Among the irrigation and water supply systems, the noria consists of conduits that criss-cross the garden to feed and irrigate it. The villa Abd-el-Tif is notable for the water distribution system. The various wells and sources of water mean that the noria is able to supply the gardens and feed several ponds, together with the guest house (douéra), following the slope of the site (see Fig. 2).

\subsection{The dream djenane (garden)}

The djenane was an ideal that was materialized through the layout and planting of various gardens that surrounded the house during the Ottoman period. The word djenane indicates a complex consisting of buildings, decorated passages, ponds and water courses, fountains and wells, places to relax, and exotic and kitchen gardens. These elements are synthesized in order to create a comfortable, pleasant space for the hot season. 
The vegetation, marine breezes and water refresh the air, while the architectural perspective is oriented towards nature: the sky, the sun and the gardens.

Inside the villa, the harmonious spatial and architectural proportions are designed to maximize views of the nature outside. These carefully chosen elements include the orthogonal and perpendicular distribution of the main living areas, and other solutions that include high windows, large rooms and the $k^{\prime}$ bou (see Figs 4 and 5). While rooms are sized to provide a view of the sky and natural lighting, the height of the windows in the k'bou and their geometry mean that there is a clear view over the garden from a shady position on the ground.

\section{CONCLUSION}

This study shows that vernacular strategies and architectural devices used in the Mediterranean region can be used as guidelines for building design. It confirms the results of many other researches $[20,21]$ carried out in other contexts and works towards the proposal of a design guide for contemporary energy efficient buildings in Mediterranean climates.

The case study - the villa Abd-el-Tif - represents an excellent synthesis of the semantic and passive aspects of Algiers' vernacular architecture. Despite the fact that this architecture has some elements that are difficult to adapt to contemporary needs, most architectural and architectonic aspects offer interesting solutions that may provide inspiration for the future development of passive architecture.

Consequently, the aesthetic description shows important passive solutions and roles, which we present in the following points:

- The open-plan principal spaces improve and facilitate natural ventilation.

- The central courtyard (called west ed-dar or patio) consists of $35 \%$ of the built surface plane (patio with galleries); this latter improves natural ventilation (both transversal and with chimney effect) into the villa. In addition, $25 \%$ of the interior envelop constitutes windows and opening (surface of $30 \mathrm{~m}^{2}$ from $128 \mathrm{~m}^{2}$ of envelop).

- All the walls are massive; they are built with stones and terra cotta bricks (their thickness is between 0.4 and $0.8 \mathrm{~m}$ ), they have high thermal capacity. Their white colour painting permits the reflection of $70 \%$ of solar radiation.

- The walls of the main rooms are covered with ceramic tiles (in both interior and exterior room walls); the ceramic tiles give high thermal isolation also.

- The presence of vegetation (plants and other flower beds) and water (fountain) in the west-ed-dar permits humidification and refreshment of the air.

- The large wooden doors (double doors) permit the control of natural ventilation.

- The galleries (called S'hin) are an intermediate area with arcs and ceramic tiles. The galleries provide shade in summer days; they prevent direct insulation and allow ventilation.

- $\quad K^{\prime}$ bou are ancillary spaces covered with cut-out cupolas. They catch the prevailing winds in summer, offer a natural ventilation (transversal and with chimney effect) and give olfactif comfort (windows on surrounding botanic gardens).

- Minzah is the terrace floor, it is covered with terra cotta and tiles. It plays the role of a fifth façade: ventilation, evacuation conducts and thermal isolation.

- Terracotta conducts evacuate and recuperate rainwater, then evacuate smokes of oil lamps and other smokes and permit the refreshment of the coming air to the rooms through conducts (by pressure of the hot-cold air).

The west-ed-dar, for example, has already imposed itself as a very efficient means of natural ventilation. It was, therefore, used in many contemporary high-rise buildings and its primary role as a climate mitigation device was largely exploited. This study introduces the derived spaces such as the 
$k^{\prime} b o u$, the galleries and the ceramic wall tiles as added values for optimizing internal comfort. Indeed, passive vernacular architecture is not reduced to a list of separate devices to be added to the main structure; it is a whole complex system with its own architectural syntax.

\section{REFERENCES}

[1] Cresti, F., Alger au XVIIe siècle, cours de post graduation à l'école polytechnique d'architecture et d'urbanisme, Centro Analisi Sociale Progetti: Rome, 1996.

[2] Ricard, P., Pour comprendre l'art musulman dans l'Afrique du nord et en Espagne, Hachette: Paris, 1924.

[3] Deluz, J.J., Le tout et le fragment, Barzakh: Alger, 2010.

[4] Fathy, H., Natural Energy and Vernacular Architecture: Principles and Examples With Reference to Hot Arid Climates, Walter Shearer and Abd-el-rahman Ahmed Sultan: Chicago and London, 1986.

[5] Ravéreau, A., La casbah d'Alger et le site créa la ville, Sinbad: Paris, 1989.

[6] Schulz, C.N., Système logique de l'architecture, Mardaga: Bruxelles, 1979.

[7] Creswall, J.W., Research Design, Qualitative, Quantitative, and Mixed Methods Approaches, 4th edn, media matrix, Sage publication: London, 2013.

[8] Cueno, P., Introduction à l'urbanisme en pays d'islam et à l'histoire des villes du Maghreb au moyen age, , cours de post-graduation de l'école polytechnique d'architecture et d'urbanisme, Alger, Centro Analisi Sociale Progetti, Rome, 1994.

[9] Chebaiki-Adli, L. \& Chabbi-Chemrouk, N., Moorish architectural syntax and the reference to nature: case study of Algiers. WIT Transactions on Ecology on The Built Environment, 142, pp. 541-551, 2014, ISSN 1743-3509 (on-line). doi: http://dx.doi.org/10.2495/arc140461

[10] Raymond, A., Le centre d'Alger en 1830, Revue de l'Occident musulman et de la Méditerranée, 31, pp. 73-84, 1981. doi: http://dx.doi.org/10.3406/remmm.1981.1905

[11] Missoum, S., Alger à l'époque Ottomane la médina et la maison traditionnelle, INAS, Alger, 2003.

[12] Golvin, L., Palais et demeures d'Alger à la période ottoman, Edisud: Alger, 1988.

[13] Giauchain, G., Alger, Société historique algérienne: Alger, 1905.

[14] Marçais, G., Manuel d'art musulman l'architecture Tunisie, Algérie, Maroc, Espagne, Sicile, tome II, Auguste Picard: Paris, 1927.

[15] Cotereau, J., La maison mauresque, les Chantiers Nord Africains Architecture Bâtiments Travaux Publics, numéro spécial, Alger, Juin 1930, pp. 531-604.

[16] Klein, H., Feuillets d'El Djezair, Imprimerie Orientale Fontana Frère \& Cie, Alger, 1910.

[17] Vidal-Bué, M., Villas et palais d'Alger du XVIIe siècle à nos jours, Places des Victoires: Paris, 2012.

[18] Holger Koch., N., The built environment (Chapter 2), Stay Cool: A Design Guide for the Built Environment in Hot Climate, Earthscan Publications: UK, 2002.

[19] Merrad, D., Evaluation de la qualité environnementale dans le secteur sauvegardé cas d'étude Casbah d'Alger, Mémoire de Magister Laboratoire Architecture et Environnement, Ecole Polytechnique d'Architecture et d'Urbanisme: Alger, 2012, pp. 139-141.

[20] Fernandes, J., The influence of the Mediterranean climate on vernacular architecture: a comparative analysis between the vernacular responsive architecture of southern Portugal and north of Egypt, World Sustainable Building Conference, Barcelona, 2014.

[21] Khashei, Z., The role of passive systems in providing comfort in traditional houses in Isfahan: a case study of the Karimi house, WIT Transactions on Ecology on the Built Environment, 128, pp. 271-280, 2010, ISSN 1743-3541 (on-line). doi: http://dx.doi.org/10.2495/arc100231 